\title{
REVIEW: INTEGRATIVE COORDINATION ABILITIES OF COACHES IN WELLNESS TYPES OF GYMNASTICS
}

\author{
Olga Aftimichuk \\ State University of Physical Education and Sports of the Republic of Moldova, Kishinev, Moldova
}

\begin{abstract}
Background. The coordination development level influences the execution of any human activity, which is very important for the general perception of this activity and behavior in general. It is especially relevant for to coaches in wellness and sports gymnastics. The aim of the present study was the identification of the coordination skills of coaches of different types of gymnastics, which would improve the process of their professional training.

Material and Methods. This review presents a synthesis of research conducted by the author. The following methods of theoretical research were used: abstract and axiomatic methods, analysis and synthesis, induction and deduction, idealization, comparison and generalization, and projecting.

Results. The coaches' training in different types of gymnastics includes the development of a wide range of professional skills: the tandem of communicative and motor skills that determine one type of complex coordination. The realization of complex coordination presupposes the participation of sensor systems (analyzer systems), which are visual, auditory, tactile, vestibular, and motor systems. The basic speech component of complex coordination in coaches' activity/behavior determines his/her communicative orientation in the process of teaching. It is explained by the connection between the cultivation of complex coordination skills with the congenital and genetic, anatomical and physiological particularities of the human organism. We determined the coordination abilities, the formation of which contributes to the development of complex coordination skills.

Conclusion. Development of integrative coordination abilities is an important part of professional activity of coaches of gymnastics, which requires such preparation.
\end{abstract}

Keywords: coordination, professional skills, coach, gymnastics, aerobics.

\section{INTRODUCTION}

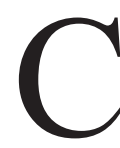
oordination, as a psycho-motor ability, is present in different spheres of human activity. To a certain degree, the coordination development level influences the style and execution manner of any activity and human behavior, which is very important for the general perception of this activity and behavior in general. In this context Vadim Zeland, a former physicist, and now a writer, suggests the notion of coordination principle (Зеланд, 2004) stating that coordination makes the shortest and the optimal path to an aim. It is especially relevant to physical education specialists, particularly, to coaches in wellness and sports types of gymnastics.
During the lessons of wellness/fitness aerobics or other group oriented gymnastics activity the coach has not only to adjust the coordinated combination of his/her muscle efforts under musical accompaniment, make a logical transition from one motor assignment to another, but he/she also has to carefully watch the execution of physical activities of the exercisers to offer them methodological recommendations if needed. That is why the coaches must possess musical-rhythmic/motor skills that are a necessary condition for the realization of these lessons (Aftimiciuc, 1997; Aftimiciuc \& Gönczi-Raicu, 1999; Liberman \& Mattingly, 1985; Scheid \& Eccles, 1975; Schoen, 1945/ 2000). 


\section{METHODS}

This review presents a synthesis of research conducted by the author. In this work we used the following methods of theoretical research: abstract and axiomatic methods, analysis and synthesis, induction and deduction, idealization, comparison and generalization, projecting and modeling.

\section{RESULTS}

Integrative coordination abilities as professional skills. The coaches' training of different types of gymnastics involves the formation of a wide range of professional skills: the tandem of communicative and motor skills that determine one type of complex coordination (Aftimiciuc, 2002; Craijdan \& Aftimiciuc, 2013; Galantucci, Fowler, \& Turvey, 2006; Liberman \& Mattingly, 1985). Furthermore, when we speak about the activity of loco-motor system, we also suppose the participation of sensor systems (analyzer systems), namely visual, auditory, tactile, vestibular, motor, which allow us to perform the transfer and processing (analysis and synthesis) of afferent information at the regulation of body movements and postures by perception. From this position the coaches of gymnastics sports must possess and use this complex set (integrative) of coordination in their professional activity, which presupposes the following types presented in Figure 1 (Gönczi-Raicu, Aftimiciuc, \& Danail, 2014).

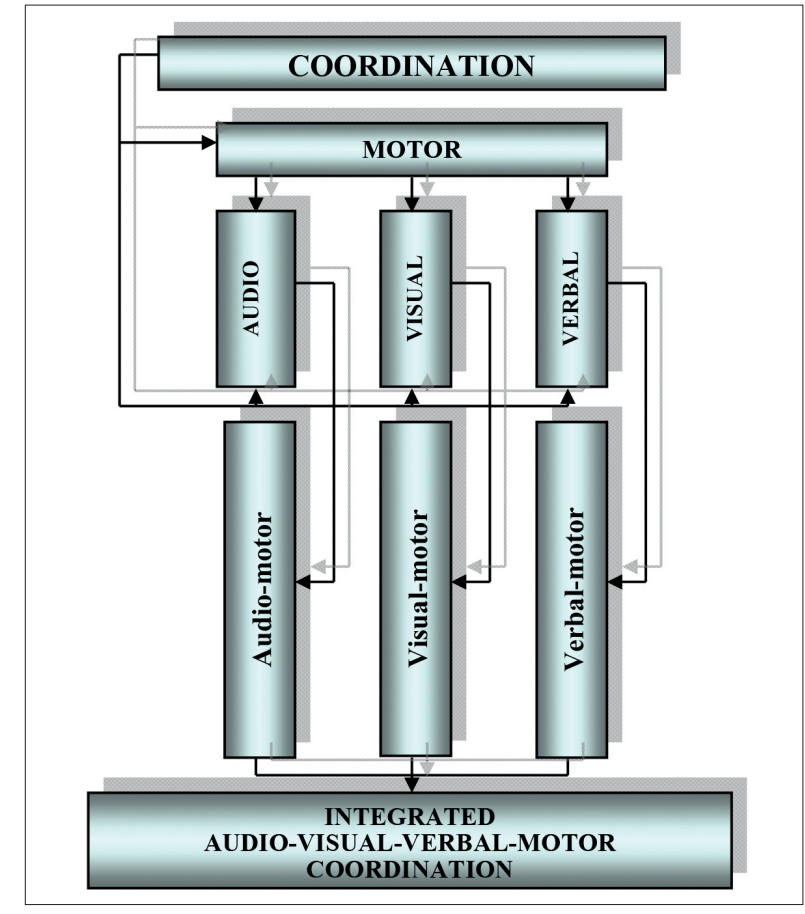

Figure 1. Types of complex coordination (Gönczi-Raicu, Aftimiciuc, \& Danail, 2014)

It should be marked that there is a certain differentiation in the content of this set of abilities for the specialists in certain types of gymnastics. For example, the possession of these abilities by the coaches of sport gymnastics is expressed in two forms. In the first case - it presupposes work with the group or the process of competitive composition development (Figure 2). The second case can appear when the coach undertakes the obligation for choreography realization (Figure 3).

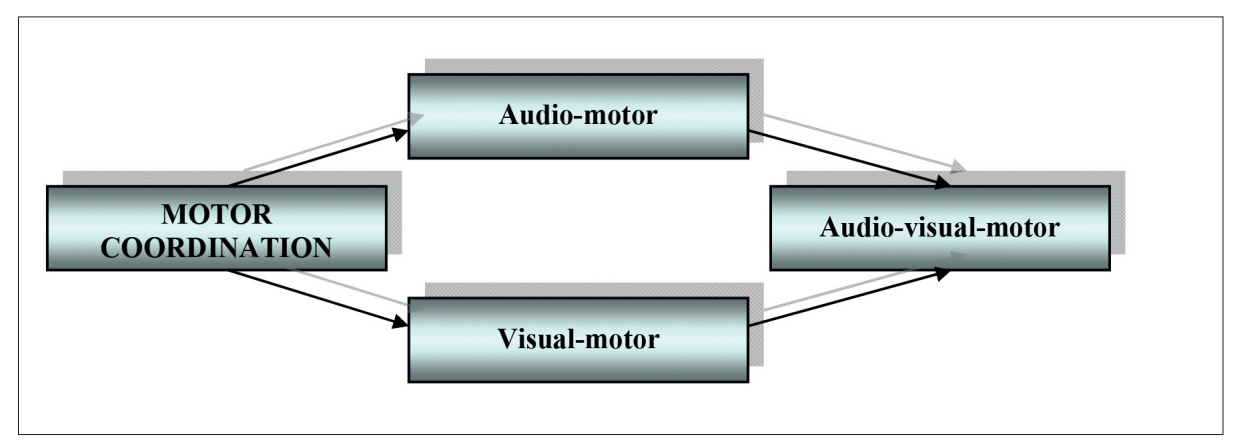

Figure 2. Variety of motor coordination during the work with the group (Faur, Aftimiciuc, \& Danail, 2014)

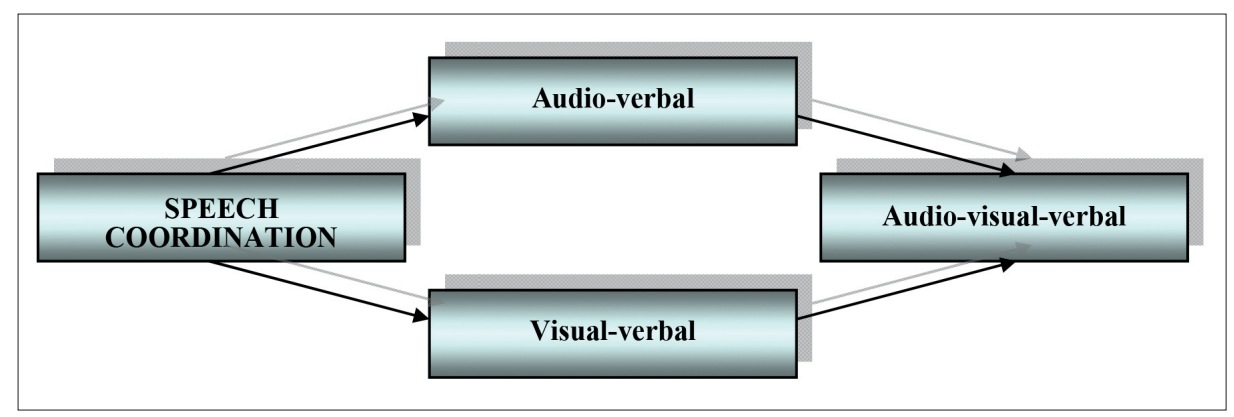

Figure 3. Types of speech coordination of the coach of sports gymnastics (Aftimiciuc, 2007) 
As we can see, in the first case the basic form of coordination is motor, which presupposes training and program elaboration (Figure 2).

Motor coordination is a one of the substantial components of motor preparation. The high level of its development is the basis of success not only in sport, but in any other professional activity (Aftimichuk \& Kuznețova, 2015; Bennett \& Riemer, 1995; Côté-Laurence, 2000; Gönczi et al., 2002; Siegenfeld, 2009). Without doubt, the level of coordination development determines the positive result of the professional activity of the coach of different types of gymnastics, where the final result of his work is determined by the level of technical competence.

The sports practice shows that the world-class sportsmen include coordination exercises that act upon specific coordination abilities for improving the processes of technique economization, deliberately emphasizing its basic components as harmonizing means that compensates the monotony of the training "for endurance" in their training programs (Лях, 1999). At the same time, the analysis of the existent literature on the problem of professional preparation of the specialists in the field of physical education did not reflect the moments of task oriented to training of coordination abilities for future coaches. Probably this is caused by the fact that in different fields of physical activity different coordination requirements are required objectively from both the coach and athlete.

In the second case basic is the speech component of complex coordination, which reflects the character of coaches' activity/behavior, which, in its turn, determines his/her communicative orientation during training (Figure 3). The presented position presupposes speech support of the execution of motor assignments that imply explanation, objections, methodological indications, etc. (Aftimiciuc, 2007).

Besides the ability to make the exercises match the musical and rhythmic composition, the following skills including the speech component are also related to them (Figure 4):

- execution of rhy thmic counting in conformity with the musical dimension;

- timely issue of instructions and special gestures for the start and finish of the exercises;

- realization of methodological discrepancies and indications in conformity with the rhythm of the exercises.

Only in this case the effect of the classes will be seen immediately. Such an integrated management of their own activities and the activities of the exercisers is seen in the skill of complex coordination (Ljach, Sadowski, \& Witkowski, 2005; Raczek, Juras, \& Waśkiewicz, 2001; Starosta, 1997).

Therefore, along with general pedagogical skills the coach of sport and wellness gymnastics must possess specific skills that precondition the existence of a set of coordination abilities, which altogether precondition the notion of coordination.

For the foregoing reasons the coordination of a coach should be considered not only as one of the characteristics of his motor and coordination capabilities. Coordination is the result of harmonized combination of movements/actions/behavior in conformity with the goal set, state of the organism and activity conditions. It has a different level of expression for a concrete person. The level of individual coordination is discovered in a successful and qualitative singularity of the organization and regulation of movements/actions or behavior altogether. At the appreciation of the coordination degree of a person it is rational to use a set of criteria (qualities) that reflect the variety of coordination abilities.

The natural basis of coordination abilities is the potential by which the congenital and hereditary anatomical and physiological particularities of the organism are understood (Ильин, 2003). They include the properties of the nervous system (strength, mobility, balance of excitation and inhibition); individual variants of cerebral cortex
Figure 5. Content of the specialized perceptions/“senses" (Craijdan \& Aftimiciuc, 2013)

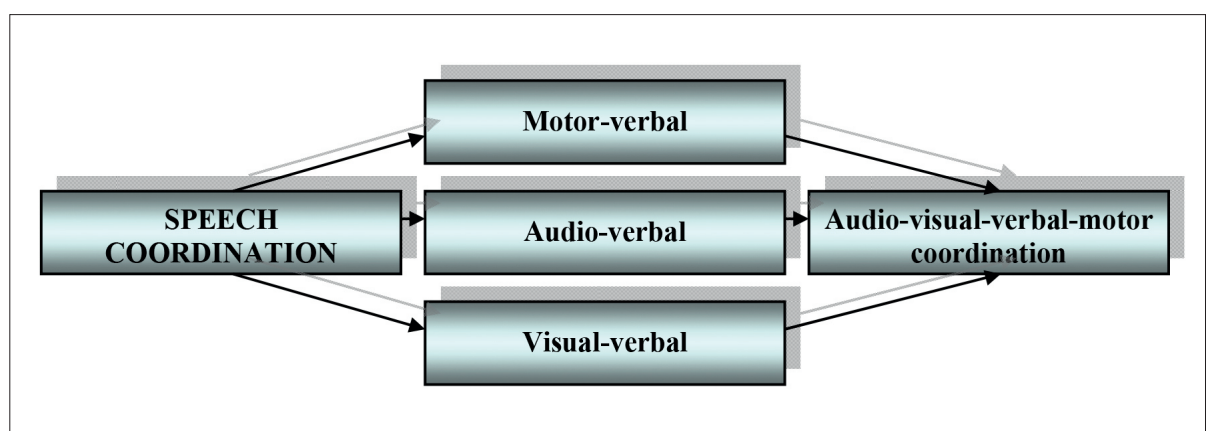




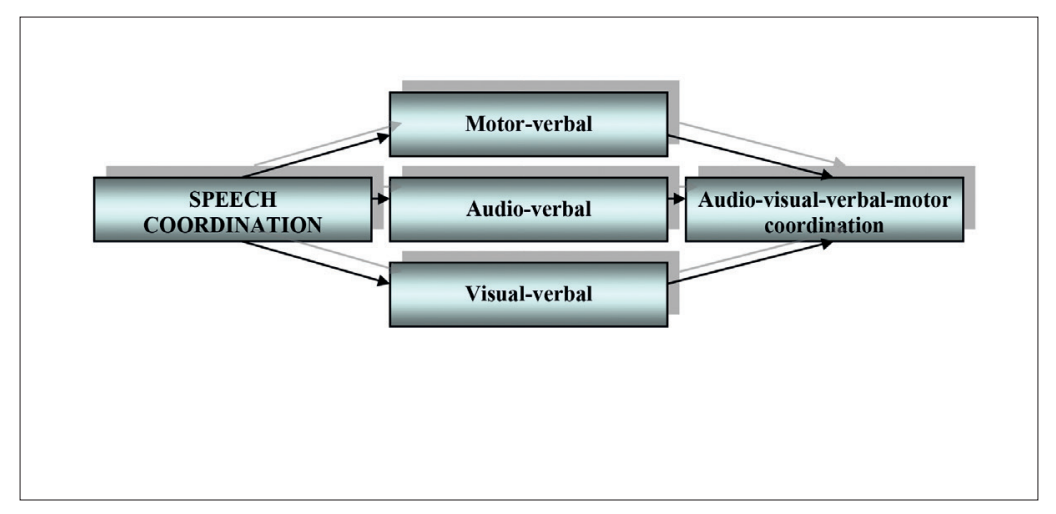

Figure 4. Types of speech coordination of a coach of the therapeutic gymnastics (Aftimichuk, 2015)

structure; maturity degree of its parts and other sections and other parts of the central nervous system; level of the development of separate analyzers (sensor systems); particularities of construction and functioning of neuromuscular apparatus; productivity ability of mental processes (sensations, perception, memory, representation, attention, thinking); temper; character; regulation and selfregulation particularities of mental state, etc.

As we can see, the aptitude for different types of coordination is determined by a set of psychophysiological factors, and the level of their preparation first of all depends on genetic particularities of the organism, which are successfully developed.

It is commonly known that the coordination abilities include:

- differentiation of different movement parameters (time, space, strength etc.);

- spatial orientation;

- balance maintaining;

- movement reforming;

- movement connection (combination);

- adaptation to a changing situation and unusual task assignment;

- execution of tasks with the given rhythm;

- time control of motor reactions;

- forestalling (anticipation) of different features of movements, conditions of their execution and track of changes altogether;

- rational relaxation of muscles.

All the above mentioned abilities do not manifest in pure form, but in a complex interaction. The majority of them are determined as specialized perceptions or "senses" (Figure 5).

As it is known, movement control is related to time parameters. They are expressed by the movement tempo and rhythm. Very often these notions replace one another in literature despite the different characteristics of movement. Tempo characterizes the amount of movements of one type in a unit of time. That is why there is the notion of high, middle and low tempo, i.e. to fast, moderate and slow tempo (Афтимичук, 2011). Basically the tempo is mentioned when the time of movements and the intervals between them are permanent. Rhythm can characterized not only by the constancy but also the variability of both the intervals between movements and the movements themselves, and its separate phases, for example, when one movement is made quickly, and the other, which is first in the combination, slowly, or when the phases of one and the same movements occupy different periods of time.

Rhythm reproduction is related to the appreciation of time intervals. In this regard such qualities as sense of time and sense of rhythm are to be considered. The sense of time represents a certain interaction between analyzer systems (visual, auditory, kinesthetic) in the process of physical actions and activity execution, which generally determines the notion of sensory-motor coordination (Zapała et al., 2014; Ильин, 2003). In sport practice the sense of rhythm is understood as the ability to reproduce the given rhythm of motor action exactly or adequately vary it depending on the changed conditions. The sense of rhythm is expressed by the exact reproduction of the direction, speed, acceleration, frequency and other characteristics of movement. Rhythm reflects the accuracy degree of the made effort, alternation of relaxation and stress phases.

Vestibular tolerance is presented by the equilibrium sense, i.e. the ability to keep the vertical position of the body irrespective of the external influence. There is static and dynamic body balance. Balance is viewed as a multicomponent motor-coordinating quality which includes:

- rational positioning of parts of the body;

- minimization of the number of freedom degrees of the moving system; 
- dosage and redistribution of muscular effort for the overcoming of the inertial force;

- space orientation.

Orientation in space is determined by the sense of space and is associated with the perception, assessment and management of spatial parameters of movement: distance to a certain object (aim); area dimension or obstacles; amplitude; direction; movement form etc. An important role in the development of the space orientation is played by the directed action in the process of physical education on the function of the analyzer systems.

The last two coordination abilities show the professional behavior of a specialist at the lessons of therapeutic aerobics. The level of their development will determine the level of methodological and practical preparation of the coach. It manifests itself in the specific character of exercise execution in aerobic regime with sufficiently intensive strength, and also in the application of methodological and didactical principles in the organization and realization of the lessons, which requires the improvement of the vestibular system of the teacher-coach.
The basis of the sense of the object/projectile is the interrelation of the functions of the analyzers tandem depending on the type of the activity or kind of sport. Following up the above mentioned facts it is worth concluding that as the classes of wellness aerobics are carried out with musical accompaniment, the specialist in this field must also possess a sense of music and musical memory, thin to feel complete musical phrases in order to correctly construct movement phrases and the whole composition.

\section{CONCLUSION}

Development of integrative coordination abilities is an important part of professional activity of the coaches of gymnastics which requires such preparation. For the purposeful development of professional motor and speech skills we suggest adding the "Musical and Rhythmic Education" working into the system of vocational preparation of coaches of the gymnastic sport as well as adopting verbal software in its content in the educational and training process of teachers and specialists in fitness.

\section{REFERENCES}

Aftimiciuc, O., \& Gönczi-Raicu, M. (1999). Probleme actuale privind formarea calităţilor integrative de coordonare în cadrul disciplinei „Educaţia ritmicomuzicală”. Timişoara: Analele Universităţii de Vest din Timişoara.

Aftimichuk, O., \& Kuznețova, Z. M. (2015). Rhythm importance in the system of professional pedagogical and sports training. Pedagogical-psychological and medico-biological problems of physical culture and sports, 2(35), 6-14. doi: 10.14526/01_1111_04

Aftimiciuc, O. (1997). Mijloacele expresivităţii muzicale în formarea vorbirii la profesorul de cultură fizică: Tendinţe şi orientări în evoluţia ştiinţei sportului şi a educaţiei fizice: Sesiune de comun. ştiinţ. Craiova, 40-43.

Aftimiciuc, O. (2002). Ritmul vorbirii şi capacitatea de coordonare în activitatea comunicativă a profesorului de cultură fizică: Impactul civilizaţiei moderne asupra educaţiei fizice şi sportului - implicaţii şi direcţii. Bucureşti.

Aftimiciuc, O. (2007). Specificul comunicării profesionale a specialistului de aerobică. Problematica educaţiei în mileniul III. Galaţi.

Aftimichuk, O. (2015). Theory and practice of rhythm in the professional training system for athletes and teaching staff. Pedagogics, Psychology, Medical-Biological Prob- lems of Physical Training and Sports, 9, 69-74. Retrieved from http://dx.doi.org/10.15561/18189172.2015.0911

Bennett, J. P., \& Riemer, P. C. (1995). Rhythmic activities and dance. USA: Human Kinetics.

Côté-Laurence, P. (2000). The Role of Rhythm in Ballet Training. Research in Dance Education, 1(2), 173-191.

Craijdan, O., \& Aftimiciuc, O. (2013). Educarea capacităților coordonative la etapa inițială a pregătirii sportive în gimnastica ritmică. Ştiinţa culturii fizice: Pregătire profesională, antrenament sportiv, educaţie fizică, recuperare, recreaţie, 15/3, 10-18.

Faur, M.-L., Aftimiciuc, O., \& Danail, S. (2014). Ritmul activităţii motrice în sistemul pregătirii profesionale pedagogice a profesorului de educaţie fizică. Chişinău: Valinex.

Galantucci, B., Fowler, C. A., \& Turvey, M. T. (2006). The motor theory of speech perception reviewed. Psychonomic Bulletin \& Review, 13(3), 361-377.

Gönczi-Raicu, M., Aftimiciuc, O., \& Danail, S. (2014). Competenţe de coordonare complexă în cadrul activităţii didactice integrative a profesorilor de educaţie fizică. Chişinău: Valinex.

Gönczi, M., Danail S., \& Aftimiciuc, O. (2002). Argumentarea conţinutului mijloacelor educaţiei ritmicomuzicale orientate spre formarea activitătii didactice 
cu structura ritmică de coordonare complexă: Impactul civilizației moderne asupra educației fizice şi sportului implicaţii şi direcții: A XII-a sesiunii anuală de comun ştiinţ. Bucureşti: Univ. Ecologică București, FEFS.

Liberman, A. M., \& Mattingly, I. G. (1985). The motor theory of speech perception revised. Cognition, 21(1), $1-36$.

Ljach, W., Sadowski, J., \& Witkowski, Z. (2005). Problems of coordination fitness control in sports (as exemplified by sports games and combat sports). In Sadowski J. (ed.), Coordination motor abilities in scientific research (pp.70-82). University School of Physical Education, Warsaw, Faculty of Physical Education, Biała Podlaska.

Raczek, J., Juras, G., \& Waśkiewicz, Z. (2001). The diagnosis of motor coordination. Journal of Human Kinetics, 6, 113-125.

Scheid, P., \& Eccles J. C. (1975). Music and speech: Artistic functions of the human brain. Psychology of Music, 3, 21-35.

Schoen, M. (2000). The understanding of music. N.Y.: Harper \& Brothers.

Siegenfeld, B. (2009). Standing down straight: Jump rhythm technique's rhythm-driven, communitydirected approach to dance education. Journal of Dance Education, 9(4), 110-119.
Starosta, W. (1997). Correlation between co-ordination and physical abilities in the theory and practice of sport training. In P. Blaser (Ed.), Proceedings book of fifth international scientific conference of International Association for Sport Kinetics. Magdeburg Theories of human motor performance and their reflection in practice (pp. 57-69). Hamburg.

Zapała, D., Zabielska-Mendyk, E., Cudo, A., Krzysztofiak, A., Augustynowicz, P., \& Francuz, P. (2014). Shortterm kinesthetic training for sensorimotor rhythms: Effects in experts and amateurs. Journal of Motor Behavior, 47(4), 312-318.

Афтимичук, О. Е. (2011). Значение развития координационных способностей у будущих специалистов по оздоровительной аэробике: Оздоровительная аэробика. Теория и методика. Кишинэу: Valinex.

Зеланд, В. (2004). Трансерфинг реальности [Электронный ресурс]. Режим доступа: http://zelands.ru/

Ильин, Е. П. (2003). Психомоторная организация человека. СПб.: Питер.

Лях, В. И. (1999). О концепциях, задачах, месте и основных положениях координационной подготовки в спорте. Теория и практика физической культуры, $5,40-46$. 